\title{
Sigillins from Springtails are Potent Natural Insecticides
}

Michael Steinbiss, ${ }^{\dagger}$ Michael Maczka,${ }^{\dagger}$ Juergen Langewald,,+ Brecht London, ${ }^{\S}$ Ramakrishnan Vallinayagam, ${ }^{\perp}$ Peter G. Jones, ${ }^{\nabla}$ Harold Bastiaans, ${ }^{*} / /$ Stefan Schulz ${ }^{\dagger} * *$

Technische Universität Braunschweig, Institute of Organic Chemistry, Hagenring 30, 38106 Braunschweig, Germany

\#BASF SE, Speyerer Strasse 2, 67117 Limburgerhof, Germany

${ }^{\S}$ BASF Corporation, 26 Davis Drive, 27709-3528 Research Triangle Park, USA

${ }^{\perp}$ BASF Chemicals India Pvt Ltd, Plot 12, TTC Area, Thane-Belapur Road, Turbhe, Navi Mumbai -400705, India

I BASF SE, Carl-Bosch-Strasse 38, 67056 Ludwigshafen, Germany

Technische Universität Braunschweig, Institute of Inorganic and Analytical Chemistry, Hagenring 30, 38106 Braunschweig, Germany

\section{Contents}

1. Synthesis 2

2. Insecticidal Activity of Sigillins 3

3. Isolation of Sigillins E and F

4. X-Ray Structure determinations 9

5. Spectra 12 


\section{Synthesis}

7-Hydroxy-8a-methyl-3-(trichloromethyl)octahydro-1 H-isochromen-1-one (6). Alkene 5 (25 mg, $0.088 \mathrm{mmol})$, obtained as described, ${ }^{1}$ was dissolved in a mixture of THF $(2.60 \mathrm{~mL})$ and $\mathrm{H}_{2} \mathrm{O}$ ( $2.16 \mathrm{~mL}) . \mathrm{Hg}(\mathrm{OAc})_{2}(84 \mathrm{mg}, 0.264 \mathrm{mmol})$ was added to the solution. After stirring for $24 \mathrm{~h} \mathrm{NaOH}$ sol. ( $3 \mathrm{M}$ in $\mathrm{H}_{2} \mathrm{O}, 0.44 \mathrm{~mL}$ ) and sodium borohydride $(7 \mathrm{mg}, 0.176 \mathrm{mmol}$ ) were added and stirring was continued for 1 min. ${ }^{15}$ The solution was extracted with EtOAc, dried with $\mathrm{MgSO}_{4}$ and concentrated under reduced pressure. The crude product was purified by column chromatography on silica gel (pentane/Et $\left.{ }_{2} \mathrm{O} 1: 2\right)$, yielding $26 \mathrm{mg}(0.086 \mathrm{mmol}, 99 \%)$ of the desired product 6 as a colorless semi-solid: ${ }^{1} \mathrm{H}$ NMR $\left(\mathrm{CDCl}_{3}, 300 \mathrm{MHz}\right) \delta 4.89(1 \mathrm{H}, \mathrm{dd}, J=9.1,5.1 \mathrm{~Hz}, \mathrm{CH}), 4.29(1 \mathrm{H}$, m, CH), 2.31-2.19 (2H, m, CH CH$_{2}, 2.03-1.94(1 \mathrm{H}, \mathrm{m}, \mathrm{CH}), 1.94-1.49(6 \mathrm{H}, \mathrm{m}, \mathrm{CH}), 1.44(3 \mathrm{H}, \mathrm{s}$, $\left.\mathrm{CH}_{3}\right) ;{ }^{13} \mathrm{C} \mathrm{NMR}\left(\mathrm{CDCl}_{3}, 75 \mathrm{MHz}\right) \delta_{\mathrm{C}} 174.6(\mathrm{COO}), 100.0\left(\mathrm{CCl}_{3}\right), 82.8(\mathrm{CH}), 66.7(\mathrm{COH}), 39.5$ $\left(\mathrm{CH}_{2}\right), 39.5(\mathrm{C}), 36.3(\mathrm{CH}), 32.2\left(\mathrm{CH}_{2}\right), 28.4\left(\mathrm{CH}_{2}\right), 22.0\left(\mathrm{CH}_{2}\right), 16.8\left(\mathrm{CH}_{3}\right)$; EIMS $\mathrm{m} / z 302[\mathrm{M}]^{+}$ (1), 284 (5), 282 (5), 219 (6), 201 (5), 183 (18), 166 (7), 165 (16), 155 (16), 153 (7), 139 (6), 138 (11), 137 (18), 131 (6), 123 (6), 121 (8), 119 (10), 117 (7), 115 (7), 113 (8), 111 (17), 110 (7), 109 (27), 107 (10), 105 (7), 98 (12), 97 (8), 95 (19), 94 (34), 93 (100), 91 (24), 85 (6), 83 (14), 82 (8), 81 (16), 80 (5), 79 (32), 77 (22), 69 (16), 68 (17), 67 (27), 65 (9), 57 (11), 55 (29), 54 (5), 53 (18), 51 (8), 44 (15), 43 (19), 42 (6), 41 (38), 40 (45), 39 (23), 36 (7).

8a-Methyl-3-(trichloromethyl)hexahydro-1 H-isochromene-1,7(3H)-dione (7). 2-Iodoxybenzoic acid $(95 \mathrm{mg}, 0.065 \mathrm{mmol})$ was added to a solution of alcohol 6 (30 mg, $0.099 \mathrm{mmol})$ in EtOAc $(7 \mathrm{~mL})$ and stirred at $80{ }^{\circ} \mathrm{C}$ for $4 \mathrm{~h} .{ }^{6}$ The reaction mixture was filtered through a plug of silica. The solvent was removed under reduced pressure yielding $30 \mathrm{mg}(0.099 \mathrm{mmol}, 99 \%)$ of pure ketone 7 as a colorless solid: ${ }^{1} \mathrm{H}$ NMR $\left(\mathrm{CDCl}_{3}, 300 \mathrm{MHz}\right) \delta 4.87(1 \mathrm{H}, \mathrm{dd}, J=9.0,5.1 \mathrm{~Hz}, \mathrm{CH}), 2.69(1 \mathrm{H}$, $\left.\mathrm{dd}, J=14.5,2.2 \mathrm{~Hz}, \mathrm{CH}_{2}\right), 2.57-2.52\left(1 \mathrm{H}, \mathrm{m}, \mathrm{CH}_{2}\right), 2.43-2.28\left(4 \mathrm{H}, \mathrm{m}, \mathrm{CH}_{2}\right), 2.09-1.89(3 \mathrm{H}, \mathrm{m}$, $\left.\mathrm{CH}_{2}, \mathrm{CH}\right), 1.66-1.57\left(1 \mathrm{H}, \mathrm{m}, \mathrm{CH}_{2}\right), 1.12(3 \mathrm{H}, \mathrm{s}, \mathrm{CH}) ;{ }^{13} \mathrm{C} \mathrm{NMR}\left(\mathrm{CDCl}_{3}, 75 \mathrm{MHz}\right) \delta_{\mathrm{C}} 207.8(\mathrm{CO})$, $172.7(\mathrm{COO}), 99.6\left(\mathrm{CCl}_{3}\right), 83.0(\mathrm{CH}), 49.5\left(\mathrm{CH}_{2}\right), 42.8(\mathrm{C}), 40.1\left(\mathrm{CH}_{2}\right), 34.9(\mathrm{CH}), 27.5\left(\mathrm{CH}_{2}\right)$, $27.1\left(\mathrm{CH}_{2}\right), 15.5\left(\mathrm{CH}_{3}\right)$; EIMS m/z $300[\mathrm{M}]^{+}(33), 298$ (34), 219 (44), 153 (100), 150 (35), 115 (42), 114 (55), 113 (74), 111 (42), 110 (53), 109 (91), 95 (36), 81 (60), 79 (35), 77 (33), 69 (37), 68 (65), 67 (62), 55 (99), 53 (40), 41 (72), 39 (48).

7-(Dichloromethylene)-8a-methyl-3-(trichloromethyl)octahydro-1H-isochromen-1-one (8). $n$ Butyllithium (1.6 M in hexanes, $1.67 \mathrm{~mL}, 2.67 \mathrm{mmol})$ was added dropwise at $-78{ }^{\circ} \mathrm{C}$ to a stirred solution of diisopropylamine $(270 \mathrm{mg}, 2.67 \mathrm{mmol})$ in anhydrous THF $(39 \mathrm{~mL})$. After stirring for $15 \mathrm{~min}$ the solution was warmed up to r.t. and cooled again to $-78{ }^{\circ} \mathrm{C}$. Ketone $7(80 \mathrm{mg}$, $0.270 \mathrm{mmol}$ ) and diethyl 1,1-dichloromethylphosphonate $(314 \mathrm{mg}, 1.35 \mathrm{mmol}$ ) were added and the mixture was allowed to warm up to r.t. over a period of $4 \mathrm{~h} .{ }^{16}$ The reaction mixture was quenched with sat. $\mathrm{NH}_{4} \mathrm{Cl}$ solution and extracted with diethyl ether. The combined organic layers were dried with $\mathrm{MgSO}_{4}$ and concentrated under reduced pressure. The crude product was purified by column 
chromatography on silica gel (pentane/diethyl ether 10:1), yielding $18 \mathrm{mg}(0.049 \mathrm{mmol}, 18 \%)$ of trideoxysigillin $(8)$ as a colorless solid: ${ }^{1} \mathrm{H}$ NMR $\left(\mathrm{CDCl}_{3}, 600 \mathrm{MHz}\right) \delta 4.90(1 \mathrm{H}, \mathrm{dd}, J=9.0,5.5$ $\mathrm{Hz}, \mathrm{CH}), 3.36\left(1 \mathrm{H}, \mathrm{dd}, J=14.3,2.2 \mathrm{~Hz}, \mathrm{CH}_{2}\right), 3.06-2.92\left(1 \mathrm{H}, \mathrm{m}, \mathrm{CH}_{2}\right), 2.34(1 \mathrm{H}, \mathrm{ddd}, J=14.5$, 6.7, $\left.5.5 \mathrm{~Hz}, \mathrm{CH}_{2}\right), 2.16-2.03\left(2 \mathrm{H}, \mathrm{m}, \mathrm{CH}_{2}\right), 1.96-1.83\left(3 \mathrm{H}, \mathrm{m}, \mathrm{CH}_{2}, \mathrm{CH}\right), 1.42-1.33\left(1 \mathrm{H}, \mathrm{m}, \mathrm{CH}_{2}\right)$, $1.15\left(3 \mathrm{H}, \mathrm{s}, \mathrm{CH}_{3}\right) ;{ }^{13} \mathrm{C} \mathrm{NMR}\left(\mathrm{CDCl}_{3}, 126 \mathrm{MHz}\right) \delta_{\mathrm{C}} 173.6(\mathrm{COO}), 132.8(\mathrm{C}), 115.9\left(\mathrm{CCl}_{2}\right), 99.6$ $\left(\mathrm{CCl}_{3}\right), 82.8(\mathrm{C}), 41.7(\mathrm{C}), 39.4\left(\mathrm{CH}_{2}\right), 35.9(\mathrm{CH}), 30.4\left(\mathrm{CH}_{2}\right), 27.9\left(\mathrm{CH}_{2}\right), 27.6\left(\mathrm{CH}_{2}\right), 14.0\left(\mathrm{CH}_{3}\right)$;

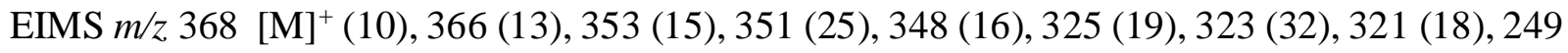
(12), 247 (11), 219 (12), 207 (47), 205 (32), 203 (13), 179 (12), 177 (70), 176 (16), 175 (100), 163 (10), 161 (15), 149 (11), 147 (12), 141 (22), 139 (40), 127 (12), 125 (20), 119 (11), 115 (12), 113 (14), 111 (32), 109 (36), 105 (25), 103 (19), 99 (11), 91 (31), 87 (12), 83 (10), 79 (13), 77 (46), 75 (15), 73 (19), 65 (19), 63 (11), 53 (14), 51 (19), 44 (34), 43 (20), 4 (22), 39 (21), 36 (11); HREIMS $\mathrm{m} / \mathrm{z} 363.9375$ (calcd for $\mathrm{C}_{12} \mathrm{H}_{13} \mathrm{Cl}_{5} \mathrm{O}_{2}, 363,9358$ ); IR (solid): $\tilde{\mathrm{v}}\left(\mathrm{cm}^{-1}\right)=2984(\mathrm{~m}), 2945$ (w), 1756 (s), 1626 (w), 1453 (m), 1341 (w), 1276 (m), 1243 (m), 1206 (m), 1149 (s), 1112 (s), $1074(\mathrm{~m})$, $991(\mathrm{w}), 903$ (m), $871(\mathrm{~m}), 811(\mathrm{~m}), 731(\mathrm{~m})$.

\section{Insecticidal Activity of Sigillins}

\section{Test 1, vetch aphid (Megoura viciae, MEGOVI) contact or systemic}

The test unit consisted of 24-well microtiter plates (TPP, Techno Plastic Products, Switzerland) containing broad bean (Vicia fabae) leaf disks $(\varnothing 15 \mathrm{~mm})$ placed on an agar plug $(\varnothing 15 \mathrm{~mm}, 5 \mathrm{~mm}$ height). The compounds were formulated using a solution containing $75 \%$ water and $25 \%$ DMSO. Different concentrations of formulated compounds were sprayed onto the leaf disks at $2.5 \mu 1$, using a custom-built micro atomizer, with two to eight replications. After application, the leaf disks were air-dried and 5-8 adult aphids placed on the leaf disks inside the microtiter plate wells. The wells were then sealed with a metal mesh (mesh opening $0.5 \mathrm{~mm}$ ). The aphids were then allowed to suck on the treated leaf disks and incubated at $23 \pm 1{ }^{\circ} \mathrm{C}, 50 \pm 5 \% \mathrm{RH}$ for 5 days (Sanyo-Parasonic incubator). Aphid mortality and fecundity was then visually assessed and the control effect rated $(0,50$, or 100$)$.

\section{Test 2, green peach aphid (Myzus persicae, MYZUPE) systemic}

The test unit consisted of 96-well microtiter plates (Greiner microlon) containing liquid artificial diet under an artificial membrane (parafilm), and a second plate for the aphids. The compounds were formulated using a solution containing $75 \%$ water and 25\% DMSO. Different concentrations of formulated compounds were pipetted into the aphid diet, using a custom built pipetter, with two to eight replications. After application, 5-8 adult aphids were placed in the second plate, and the second plate was placed on top of the first plate containing the artificial diet. After flipping the two plates, the aphids were able to suck on the treated aphid diet and incubated at $23 \pm 1{ }^{\circ} \mathrm{C}, 50 \pm 5 \% \mathrm{RH}$ for 3 days (Sanyo-Parasonic incubator). Aphid mortality and fecundity was then visually assessed and the control effect rated $(0,50$, or 100$)$. 


\section{Test 3, boll weevil (Anthonomus grandis, ANTHGR)}

The test unit consisted of 96-well microtiter plates containing an artificial insect diet and 20-30 A. grandis eggs. The compounds were formulated using a solution containing $75 \%$ water and $25 \%$ DMSO. Different concentrations of formulated compounds were sprayed onto the insect diet at $5 \mu 1$, using a custom-built micro atomizer, with two to eight replications. After application, the microtiter plates were sealed with a plastic foil containing 4 aeration holes per well (viewseal, Greiner bio one). The microtiter plates were then incubated at $23 \pm 1{ }^{\circ} \mathrm{C}, 50 \pm 5 \% \mathrm{RH}$ for 5 days (Sanyo-Parasonic incubator). Egg and larval mortality were then visually assessed and the control effect rated $(0,50$, or 100$)$.

\section{Test 4, tobacco budworm (Heliothis virescens, HELIVI)}

The test unit consisted of 96-well microtiter plates containing an artificial insect diet and 15-25 $\mathrm{H}$. virescens eggs. The compounds were formulated using a solution containing $75 \%$ water and $25 \%$ DMSO. Different concentrations of formulated compounds were sprayed onto the insect diet at $10 \mu 1$, using a custom micro atomizer, with two to eight replications. After application, the microtiter plates were sealed with a plastic foil containing four aeration holes per well (viewseal, greiner bio one). The microtiter plates were then incubated at $28 \pm 1{ }^{\circ} \mathrm{C}, 80 \pm 5 \% \mathrm{RH}$ for 5 days (Sanyo-Parasonic incubator). Egg and larval mortality were then visually assessed and the control effect rated $(0,50$, or 100$)$.

\section{Test 5, yellow fever mosquito (Aedes aegypti, AEDSAE)}

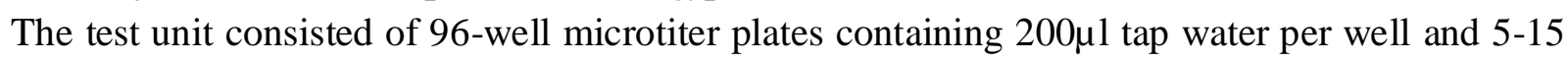
freshly hatched A. aegypti larvae. The compounds were formulated using a solution containing $75 \%$ water and $25 \%$ DMSO. Different concentrations of formulated compounds or mixtures were sprayed onto the insect diet at $2.5 \mu 1$, using a custom-built micro atomizer, at two to eight replications. After application, the microtiter plates were sealed with a plastic foil containing 4 aeration holes per well (viewseal, greiner bio one). The microtiter plates were then incubated at $28 \pm 1{ }^{\circ} \mathrm{C}, 80 \pm 5 \% \mathrm{RH}$ for 2 days (Sanyo-Parasonic incubator). Larval mortality was then visually assessed, and the control effect rated $(0,50$, or 100$)$.

\section{Test 6, greenhouse whitefly (Trialeurodes vaporariorum, TRIAVI)}

The test unit consisted of 96-well microtiter plates containing a leaf disk (Ø5 mm) of eggplant (Solanum melongena) placed on an agar plug (Ø5 mm, $3 \mathrm{~mm}$ height) with white fly eggs. The compounds were formulated using a solution containing $75 \%$ water and 25\% DMSO. Different concentrations of formulated compounds were sprayed onto the leaf disks at $2.5 \mu 1$, using a custombuilt micro atomizer, with two to eight replications. After application, the microtiter plates were sealed with a plastic foil containing 4 aeration holes per well (viewseal, greiner bio one). The 
microtiter plates were then incubated at $23 \pm 1{ }^{\circ} \mathrm{C}, 65 \pm 5 \% \mathrm{RH}$ for 6 days. Mortality of hatched crawlers was then visually assessed, and the control effect rated $(0,50$, or 100).

\section{Test 7, silverleaf whitefly (Bemisa argentifoli, BEMIAR)}

The test unit consisted of cotton (Gossypium sp.) plants in $5 \times 5 \mathrm{~cm}$ plastic pots (growth stage $\mathrm{BBCH}$ 10). The final spray solutions of $300 \mathrm{ppm}$ was prepared in a scintillation vial (AssemPack, Vineland, NJ), with diluent of 1:1 acetone/water, and with $0.01 \%(\mathrm{v} / \mathrm{v})$ of Kinetic HV added as surfactant. The spray solutions was applied at a volume of $15.5 \mathrm{ml}$ per plant using a custom built sprayer. When the plants were dry, 10-12 adult silverleaf whiteflies (approximately 3-5 days of age) were added to each plant.

The infested plants were covered with a transparent plastic cup and then at $26 \pm 3{ }^{\circ} \mathrm{C}, 20-60 \%$ RH and 14L:10D photoperiod incubated. After three days the mortality of adult whiteflies was visually assessed, and the control effect rated $(0,25,50,75,90$ or 100).

\section{Test 8, orchid thrips (Dichromothrips corbetti, ANAPCO)}

The test unit consisted of fresh petals of Vanda orchid flowers (Vanda sp.). The final test solutions of $300 \mathrm{ppm}$ was prepared in a scintillation vial (AssemPack, Vineland, NJ), with diluent of 1:1 acetone:water, and with $0.01 \%(\mathrm{v} / \mathrm{v})$ of Kinetic HV added as surfactant. The test solutions was applied by dipping the orchid petals for three seconds into the solution in a petri dish. The petals were then placed on a paper towel for drying. When dry, each petal was placed in an individual zipper plastic bag and infested with 20 adult orchid thrips. The infested petals were then incubated at $27 \pm 3{ }^{\circ} \mathrm{C}, 50 \% \mathrm{RH}$ in total darkness. After 3 days mortality of adult thrips was visually assessed, and the control effect rated $(0,25,50,75$, or 100$)$.

\section{Test 9, cowpea aphid (Aphis craccivora, APHICR)}

The test unit consisted of five day old bush bean (Phaseolus vulgaris) seedlings in $5 \times 5 \mathrm{~cm}$ plastic pots with removed apical leaves. The final spray solutions of $300 \mathrm{ppm}$ was prepared in a scintillation vial (AssemPack, Vineland, NJ), with diluent of 1:1 acetone:water, and with $0.01 \%$ (v/v) of Kinetic HV added as surfactant. The spray solutions was applied at a volume of $2 \mathrm{ml}$ per plant using a hand held laboratory sprayer. When the plants were dry the soil surface of the pots was covered with a slotted filter paper and 30-50 mixed stage aphids were added to each plant. The infested plants were covered with a transparent plastic cup and then incubated at $27 \pm 3{ }^{\circ} \mathrm{C}, 50 \% \mathrm{RH}$ and 14L:10D photoperiod. After three days mortality of adult whiteflies was then visually assessed, and the control effect rated $(0,25,50,75$ or 100$)$.

\section{Test 10, diamond back moth (Plutella xylostella, PLUTMA)}

The test unit consisted of leaf disks ( $6 \mathrm{~cm}$ diameter) from cabbage (Brassica oleracea) leaves. The final spray solutions of $300 \mathrm{ppm}$ was prepared in a scintillation vial (AssemPack, Vineland, NJ), with diluent of 1:1 acetone:water, and with $0.01 \%(\mathrm{v} / \mathrm{v})$ of Kinetic HV added as surfactant. The 
spray solutions was applied by dipping the leaf disks in the treatment solution for three seconds. Each disk was then placed on filter paper in an individual petri dishes $(100 \times 15 \mathrm{~mm})$ and when the disk was dry, infested with third instar caterpillars. The petri dishes were then covered with a soft paper towel and closed, incubated at $24 \pm 3{ }^{\circ} \mathrm{C}, 35 \% \mathrm{RH}$ in total darkness. After three days mortality of the caterpillars was then visually assessed, and the control effect rated $(0,25,50,75$ or 100). 


\section{Isolation of Sigillins $\mathbf{E}$ and $F$}

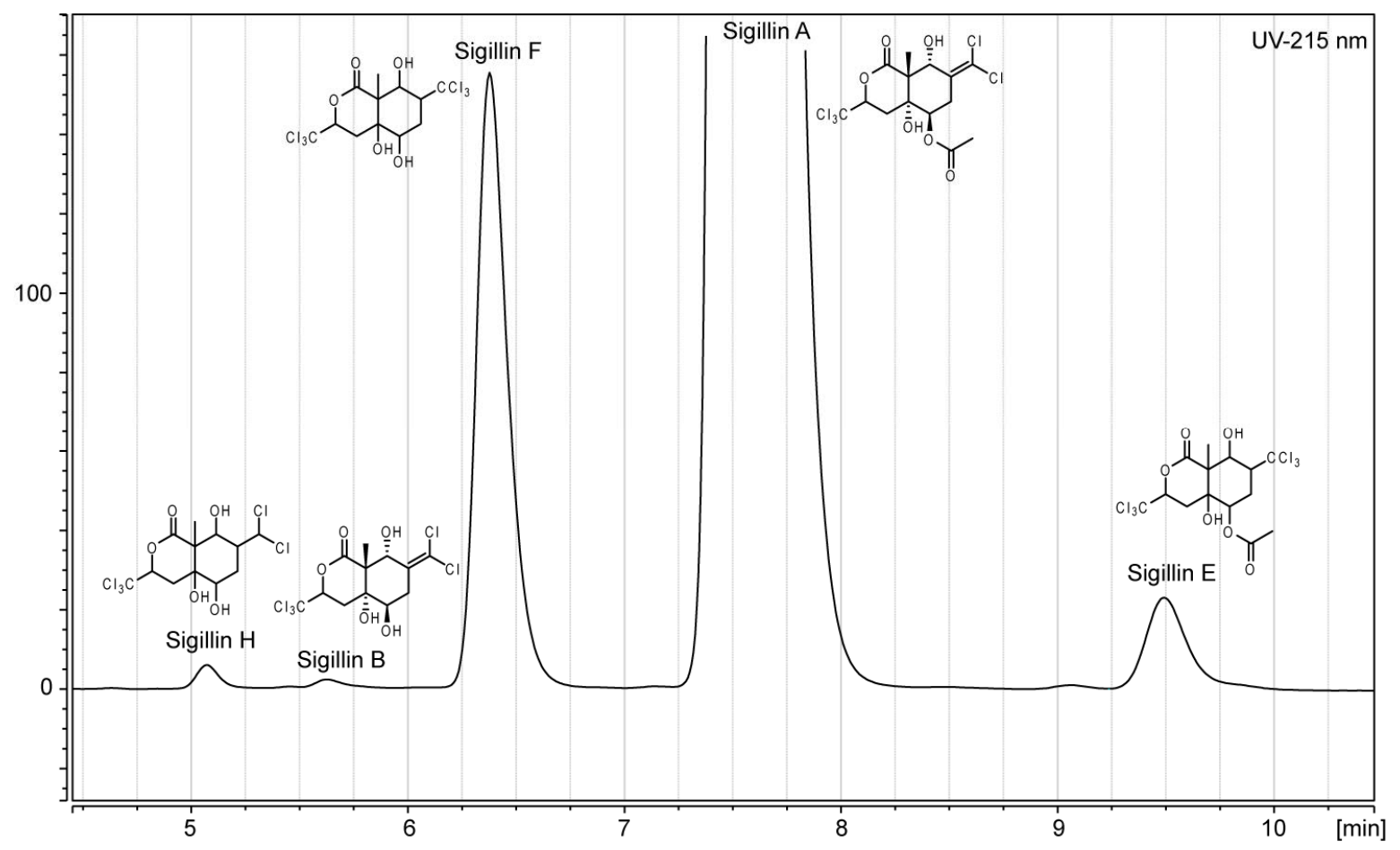

Figure S1. HPLC/DAAD separation of sigillins on a $250 \mathrm{~mm}$ RP-18 column with isocratic elution with $60 \%$ acetonitrile/water. Sigillin F (4) and sigillin E (3) were isolated. 


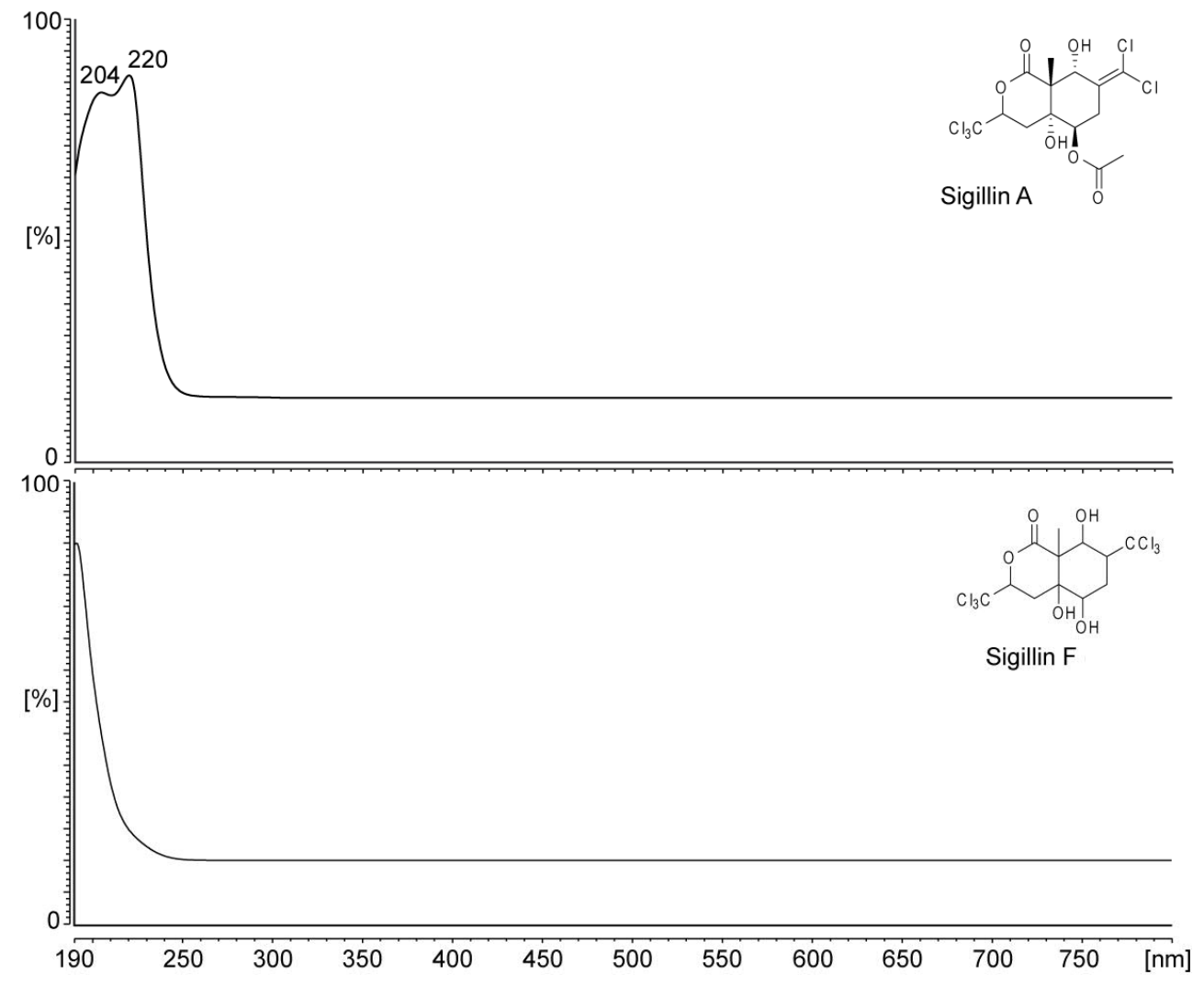

Figure S2. UV-spectra of sigillin A (1) and sigillin F (4). 


\section{X-Ray Structure determinations}

Sigillin F (4). Details were given in the main paper.

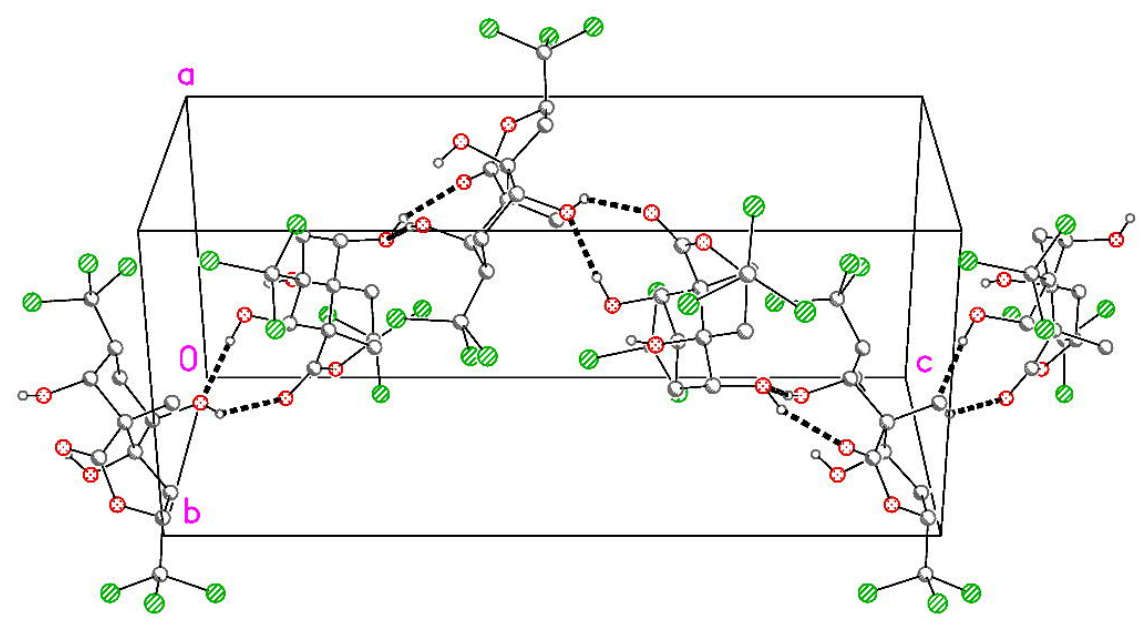

Figure S3. Packing diagram of sigillin F (4). The thick dashed lines indicate intermolecular hydrogen bonds O3-H03...O5 and O5-H05... O1, with H...O 1.94(3), 2.08(5) $\AA$ and O-H...O 171(4), $138(5)^{\circ}$ respectively, which link the molecules via the $4_{1}$ axis to form spiral ribbons. Hydrogen atoms not involved in hydrogen bonds are omitted.

Trideoxysigillin (8). Single crystals were obtained by diffusion of $n$-pentane into a solution of the compound in dichloromethane. Data were recorded on an Oxford Diffraction Xcalibur E diffractometer using monochromated Mo K $\alpha$ radiation $(\lambda=0.71073 \AA$ ). The structure was solved by direct methods using SHELXS-97 and refined with SHELXL-2017. All non-hydrogen atoms were refined anisotropically. Methyl groups were refined as idealized rigid groups allowed to rotate but not tip. Other hydrogen atoms were included using a riding model starting from calculated positions. Crystal data have been deposited at the Cambridge Crystallographic Data Centre under the number CCDC-1944423, and can be obtained via www.ccdc.cam.ac.uk/structures.

Crystal data of trideoxysigillin (8): $\mathrm{C}_{12} \mathrm{H}_{13} \mathrm{Cl}_{5} \mathrm{O}_{2}, M_{\mathrm{r}}=366.47$, monoclinic, $a=18.0710$ (4), $b=$ 9.5329(2), $c=17.7642(5) \AA, \beta=99.613(3)^{\circ}, V=3017.26 \AA^{3}$, space group $P 2{ }_{1} / c, Z=8, T=100$ $\mathrm{K}, d_{\text {calc }}=1.614 \mathrm{Mg} \mathrm{m}^{-3}, \mu=0.96 \mathrm{~mm}^{-1}, F(000)=1488$. Crystal dimensions $0.35 \times 0.35 \times 0.25$ $\mathrm{mm}^{3}$. Reflections: 132448 registered to $2 \theta_{\max } 60^{\circ}, 8782$ unique $\left(R_{\text {int }}=0.049\right)$. Final $w R 2$ (all data) $=0.076, R 1(F>4 \sigma(F))=0.035 ; \mathrm{GOOF}=1.06, \max . \Delta \rho=1.2 \mathrm{e} \AA^{-3}$. 


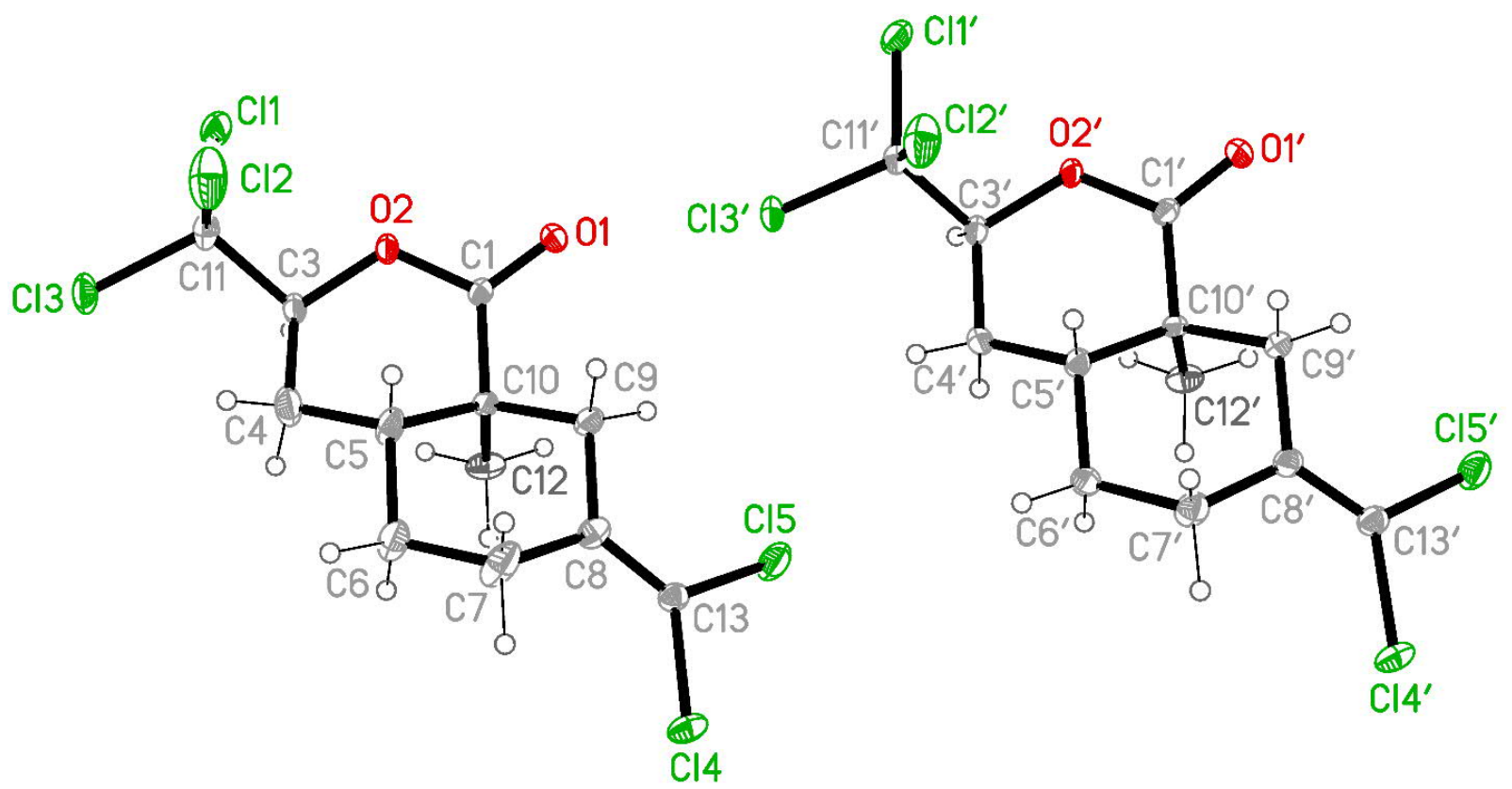

Figure S4. Thermal ellipsoid plot (50\% level) of trideoxysigillin (8). The compound crystallizes with two independent molecules in the asymmetric unit. 


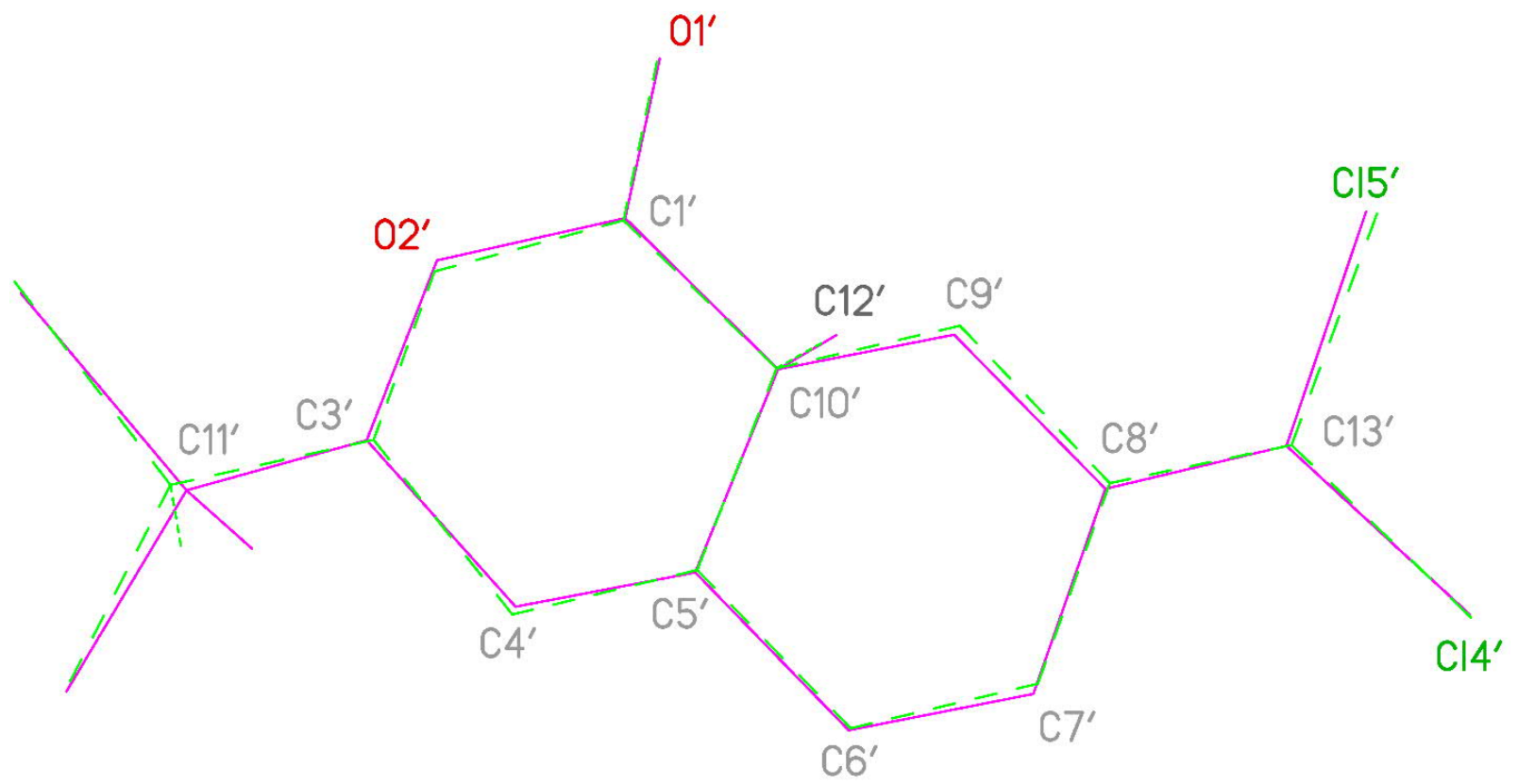

Figure S5. Least-squares fit of both molecules of trideoxysigillin (8). All non-hydrogen atoms except the chlorine atoms of the trichloromethyl groups (for which a significant difference in orientation can be recognized) were fitted, with a root mean square deviation of $0.13 \AA$. 


\section{Spectra}

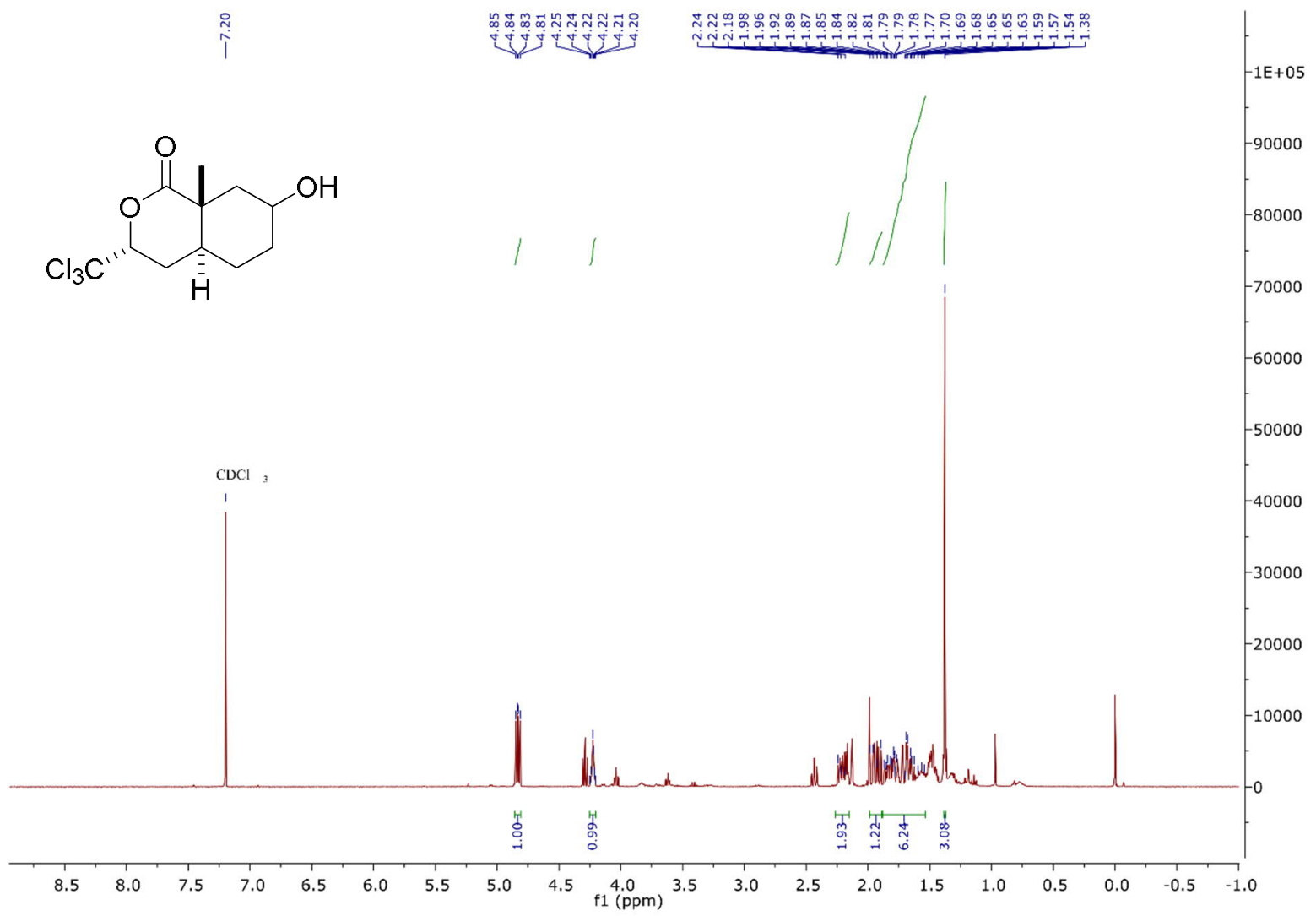

Figure S6. ${ }^{1} \mathrm{H} \mathrm{NMR}\left(300 \mathrm{MHz}, \mathrm{CDCl}_{3}\right)$ spectrum of the new compound 6. 


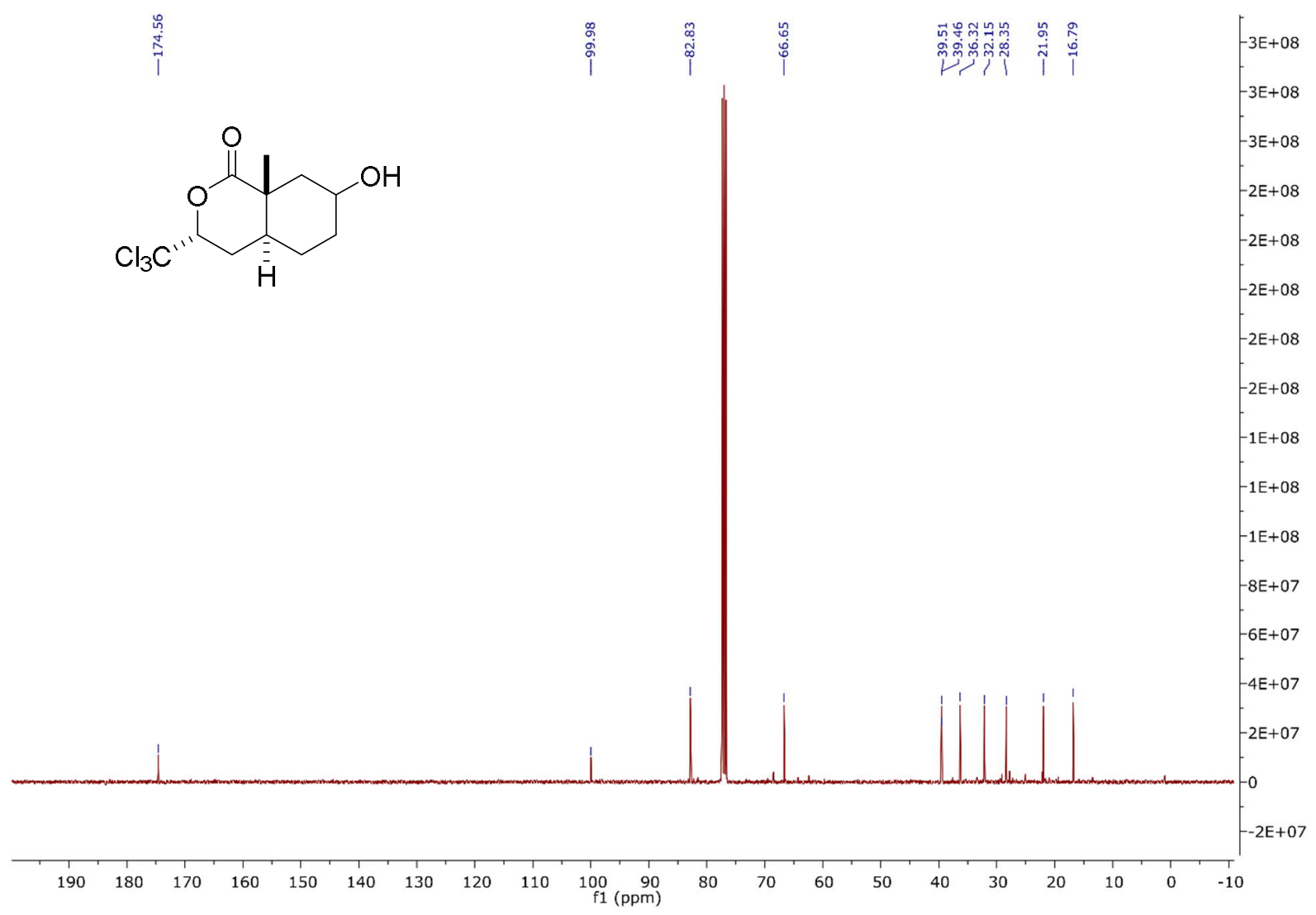

Figure S7. ${ }^{13} \mathrm{C} \mathrm{NMR}\left(75 \mathrm{MHz}, \mathrm{CDCl}_{3}\right)$ spectrum of the new compound 6. 


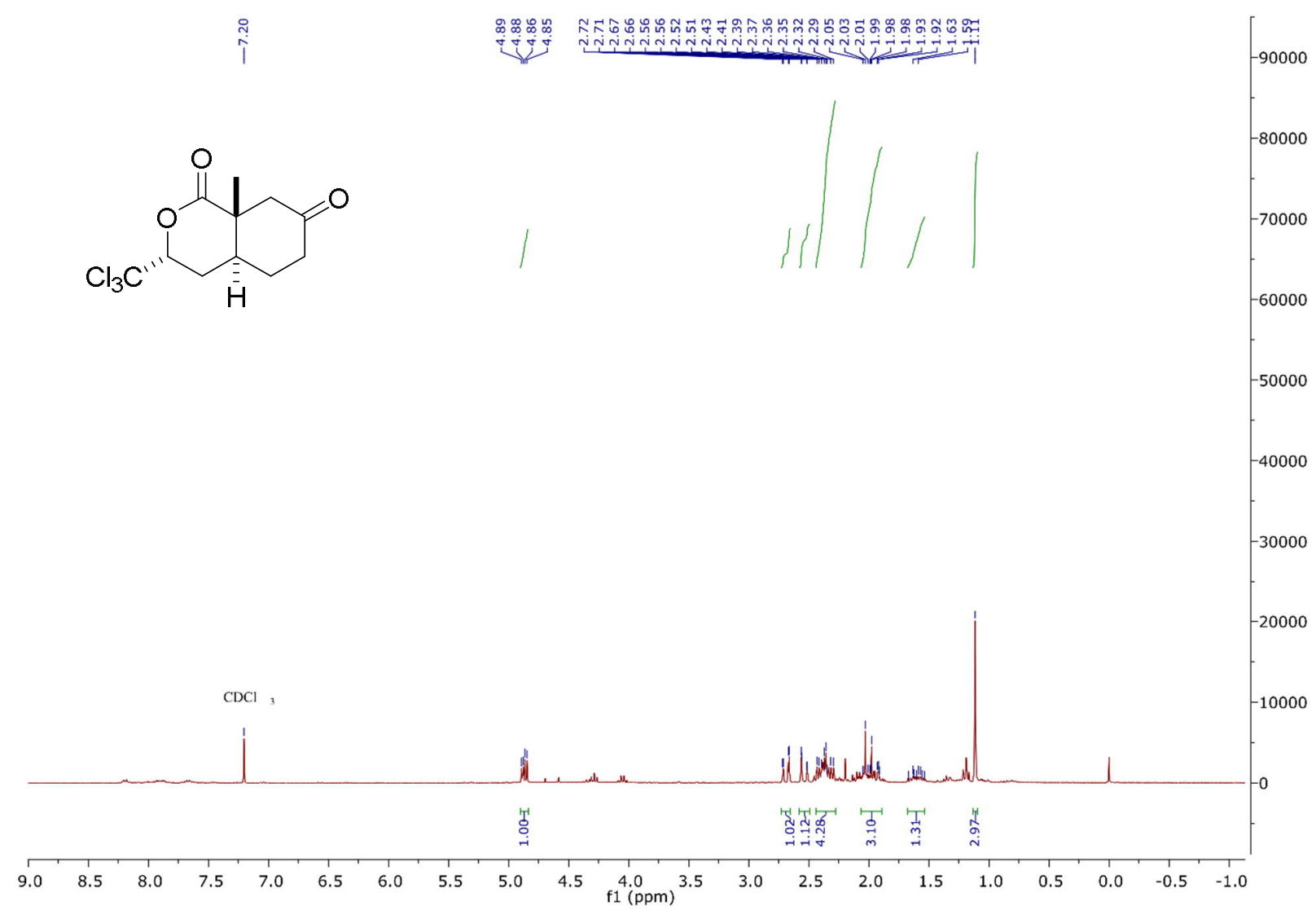

Figure S8. ${ }^{1} \mathrm{H} \mathrm{NMR}\left(300 \mathrm{MHz}, \mathrm{CDCl}_{3}\right)$ spectrum of the new compound 7. 


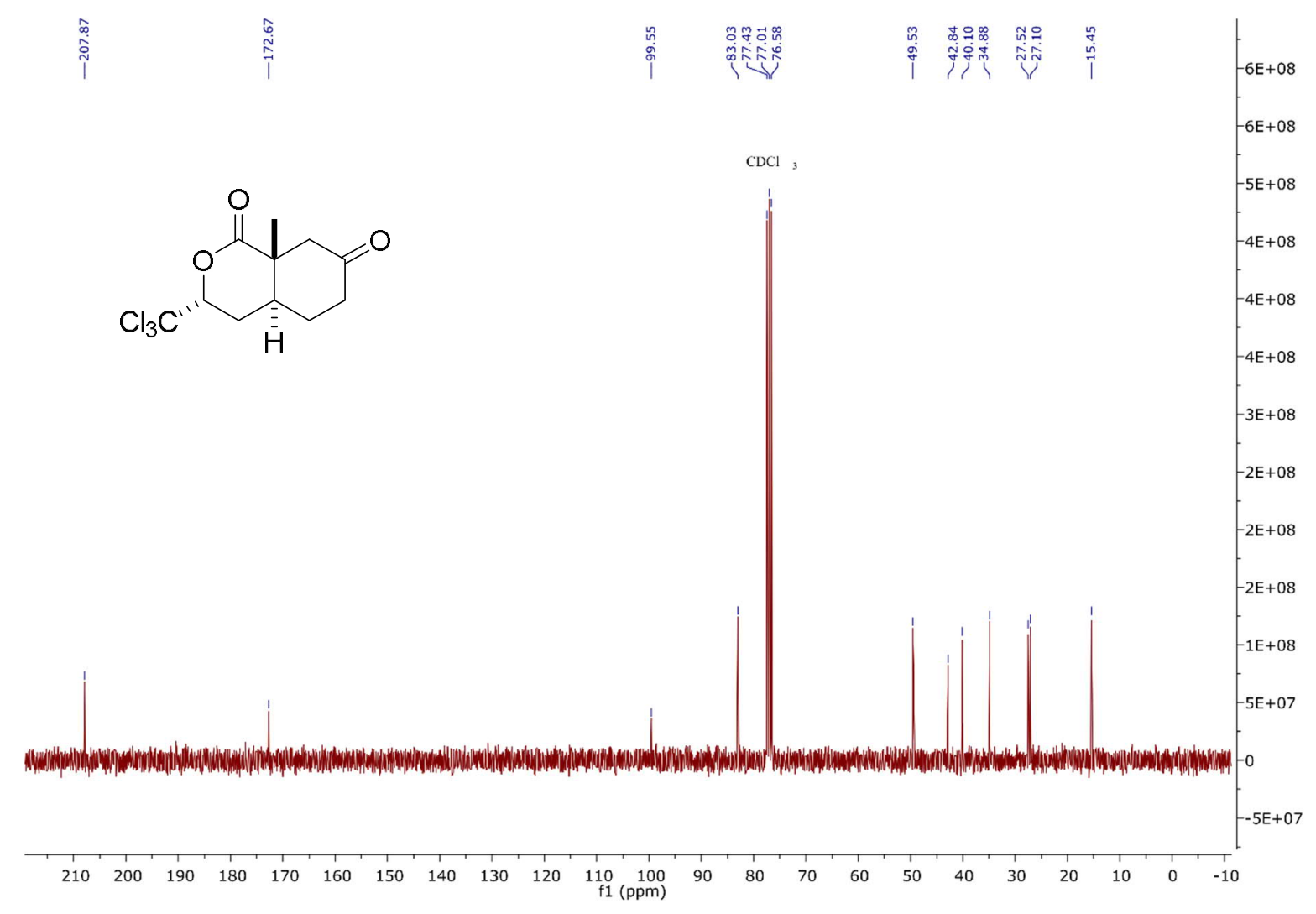

Figure S9. ${ }^{13} \mathrm{C} \mathrm{NMR}\left(75 \mathrm{MHz}, \mathrm{CDCl}_{3}\right)$ spectrum of the new compound 7. 


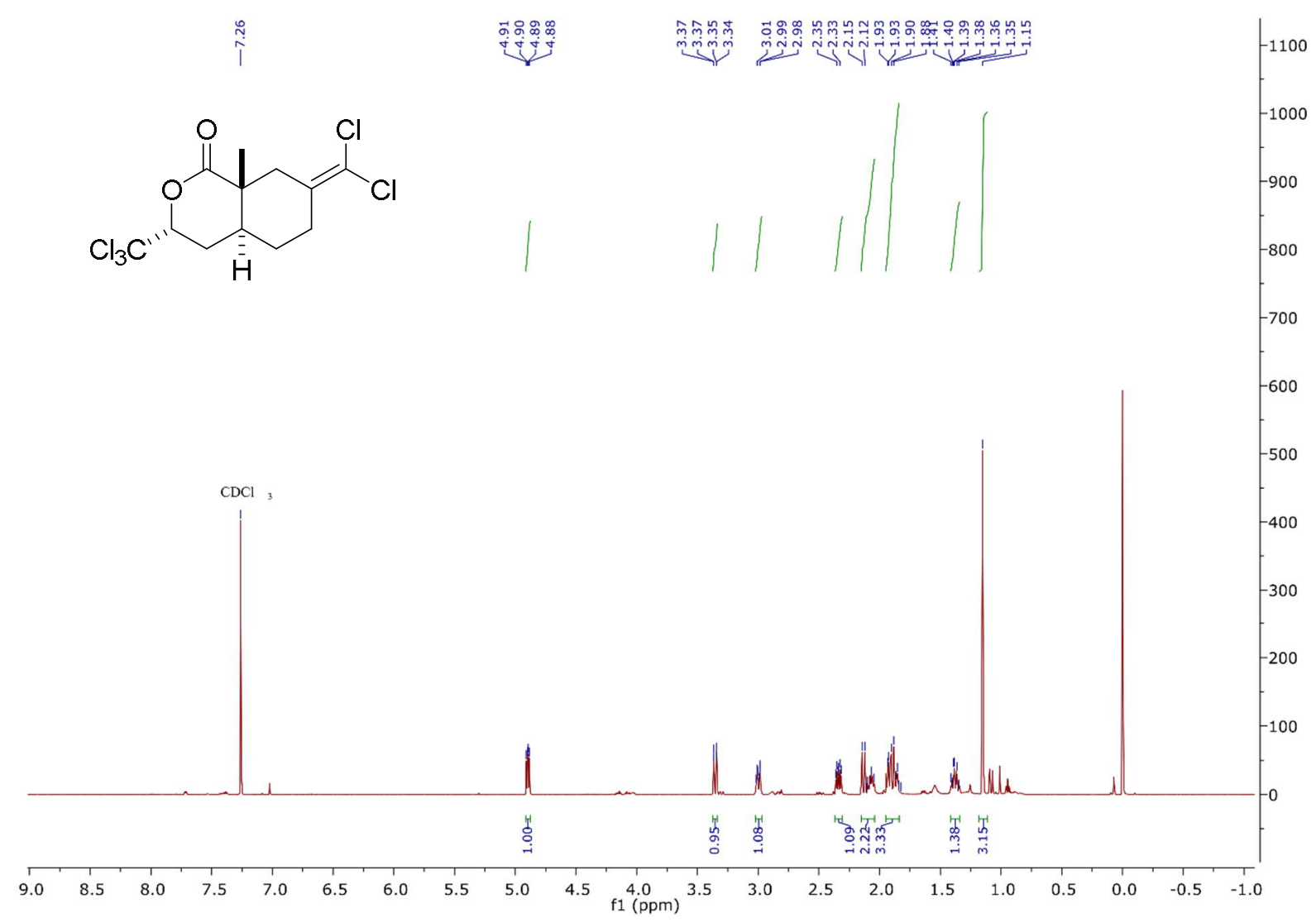

Figure S10. ${ }^{1} \mathrm{H}$ NMR $\left(600 \mathrm{MHz}, \mathrm{CDCl}_{3}\right)$ spectrum of trideoxysigillin (8). 


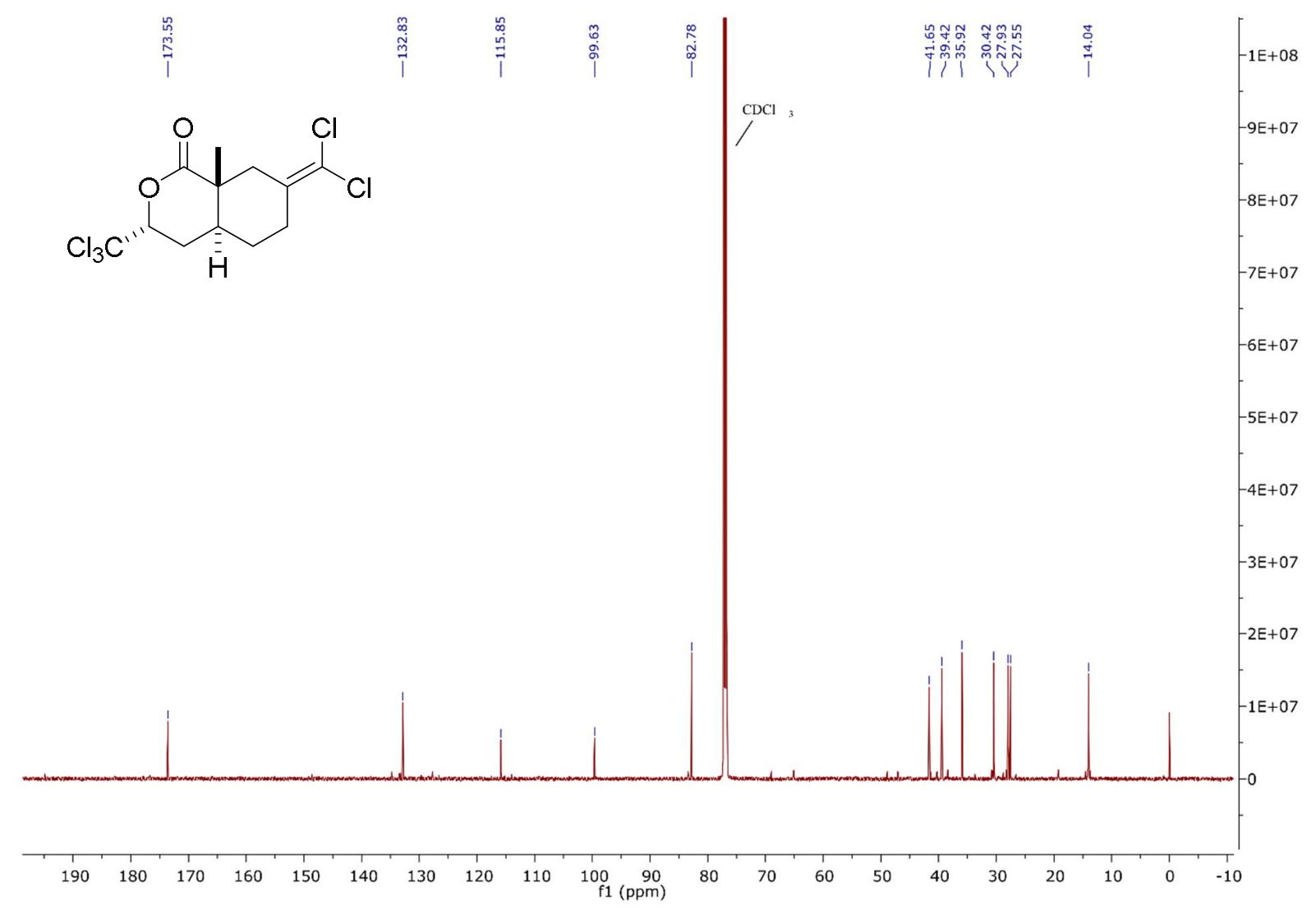

Figure S11. ${ }^{13} \mathrm{C} \mathrm{NMR}\left(126 \mathrm{MHz}, \mathrm{CDCl}_{3}\right)$ spectrum of trideoxysigillin (8).

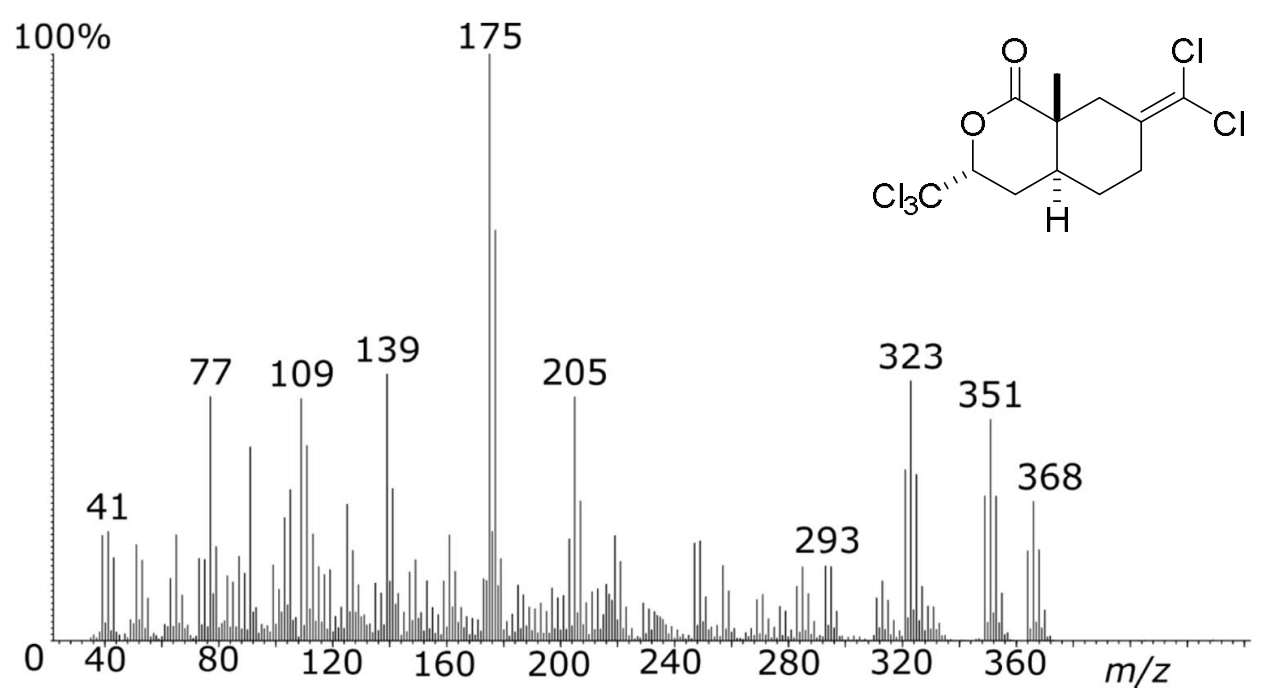

Figure S12. Mass spectrum (EI) of trideoxysigillin (8). 


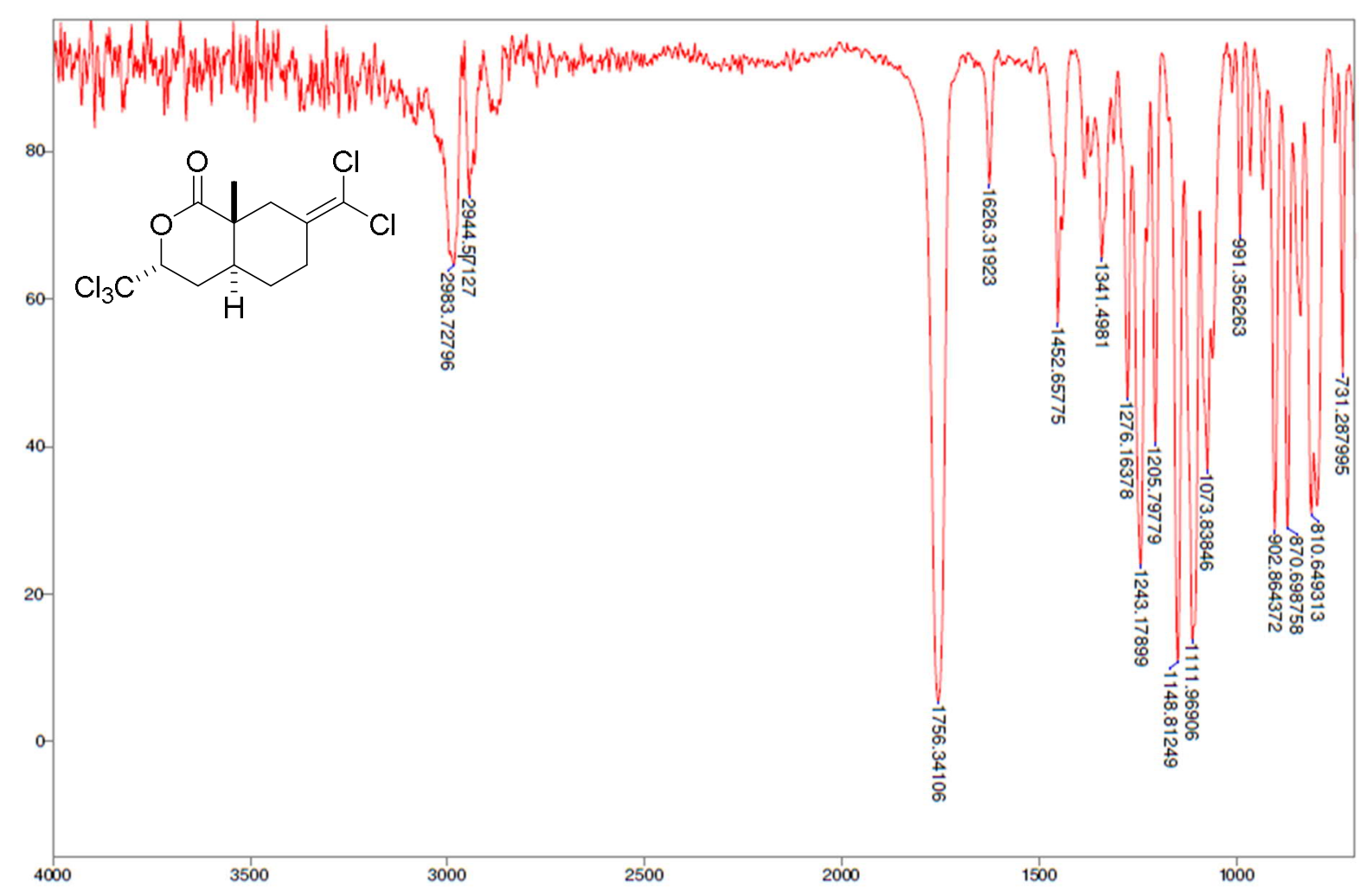

Figure 13. Solid phase IR spectrum of trideoxysigillin (8). 


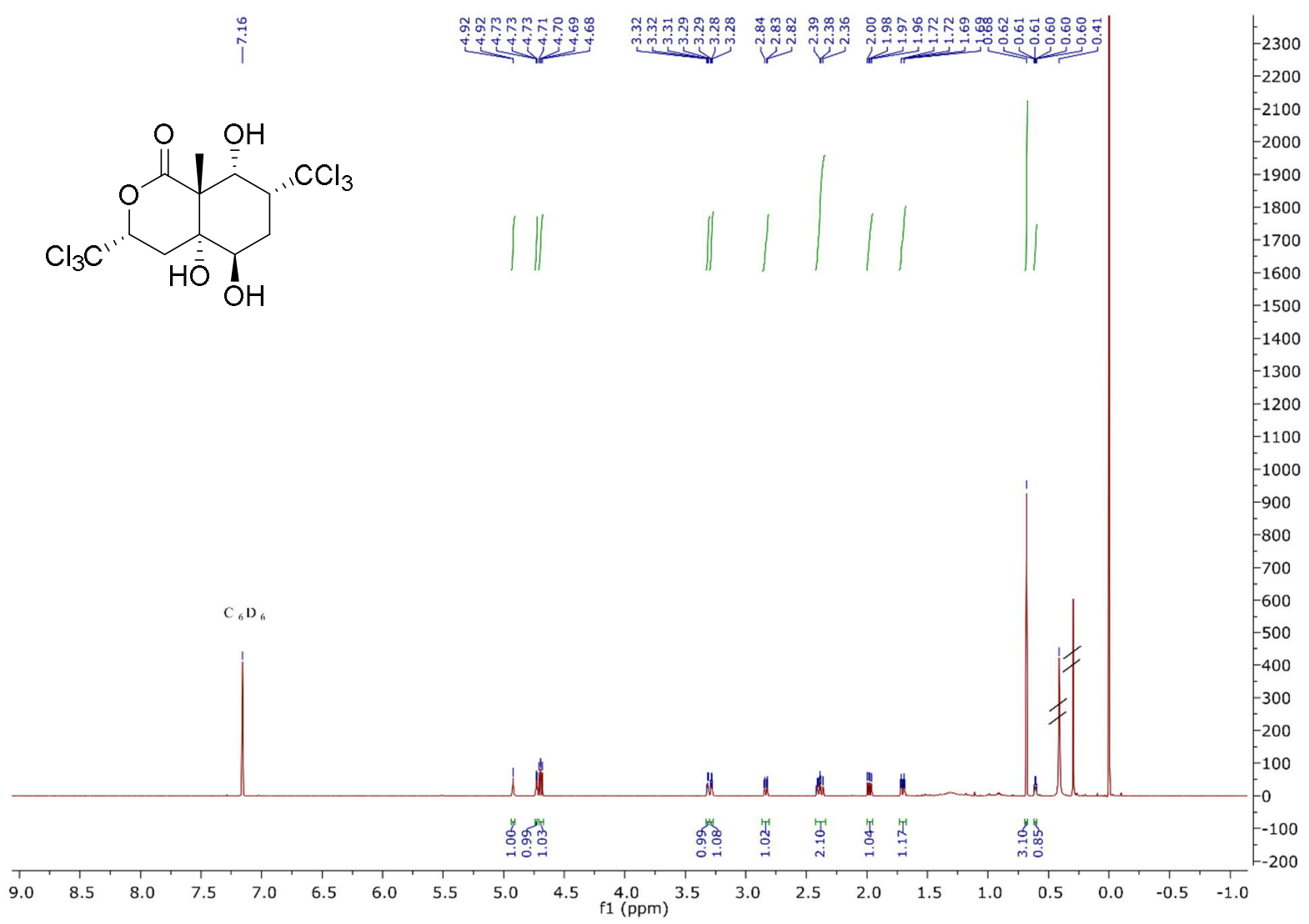

Figure S14. ${ }^{1} \mathrm{H}$ NMR $\left(600 \mathrm{MHz}, \mathrm{C}_{6} \mathrm{D}_{6}\right)$ spectrum of sigillin $\mathrm{F}(\mathbf{4})$. 


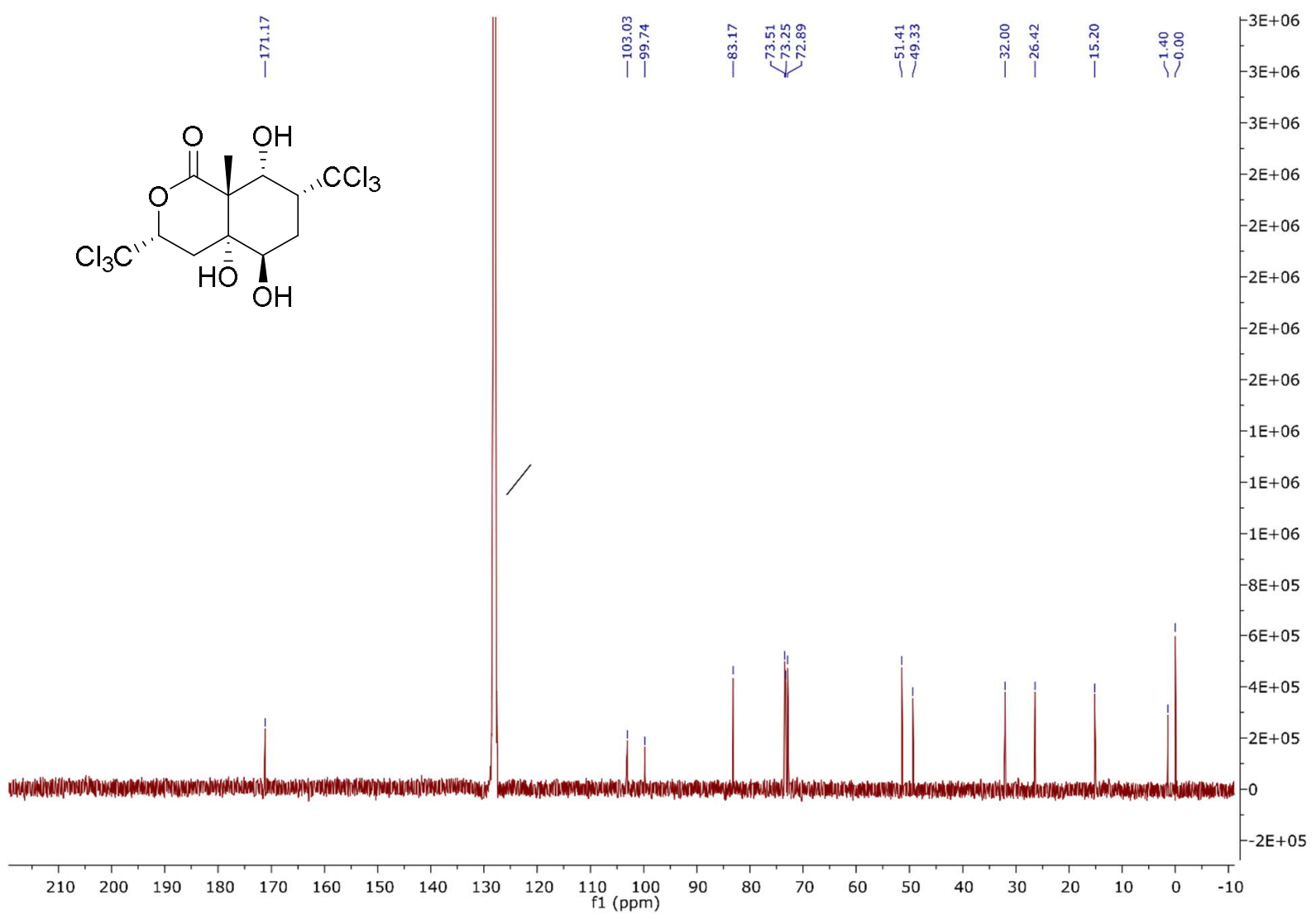

Figure S15. ${ }^{13} \mathrm{C}$ NMR (150 MHz, $\mathrm{C}_{6} \mathrm{D}_{6}$ ) spectrum of sigillin $\mathrm{F}(\mathbf{4})$. 


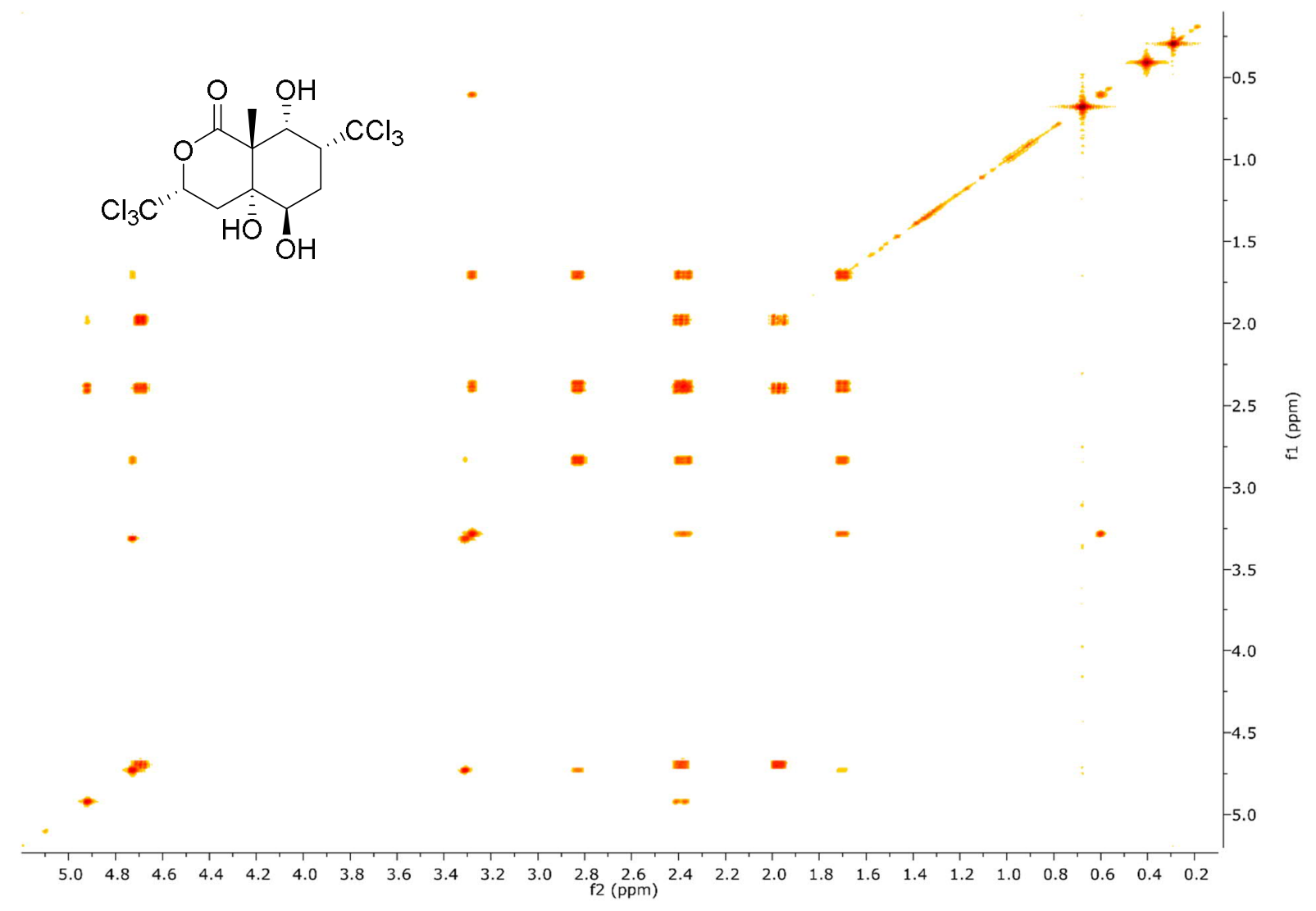

Figure S16. ${ }^{1} \mathrm{H},{ }^{1} \mathrm{H}-\mathrm{COSY}$-spectrum of sigillin $\mathrm{F}(4)$ in $\mathrm{C}_{6} \mathrm{D}_{6}$. 


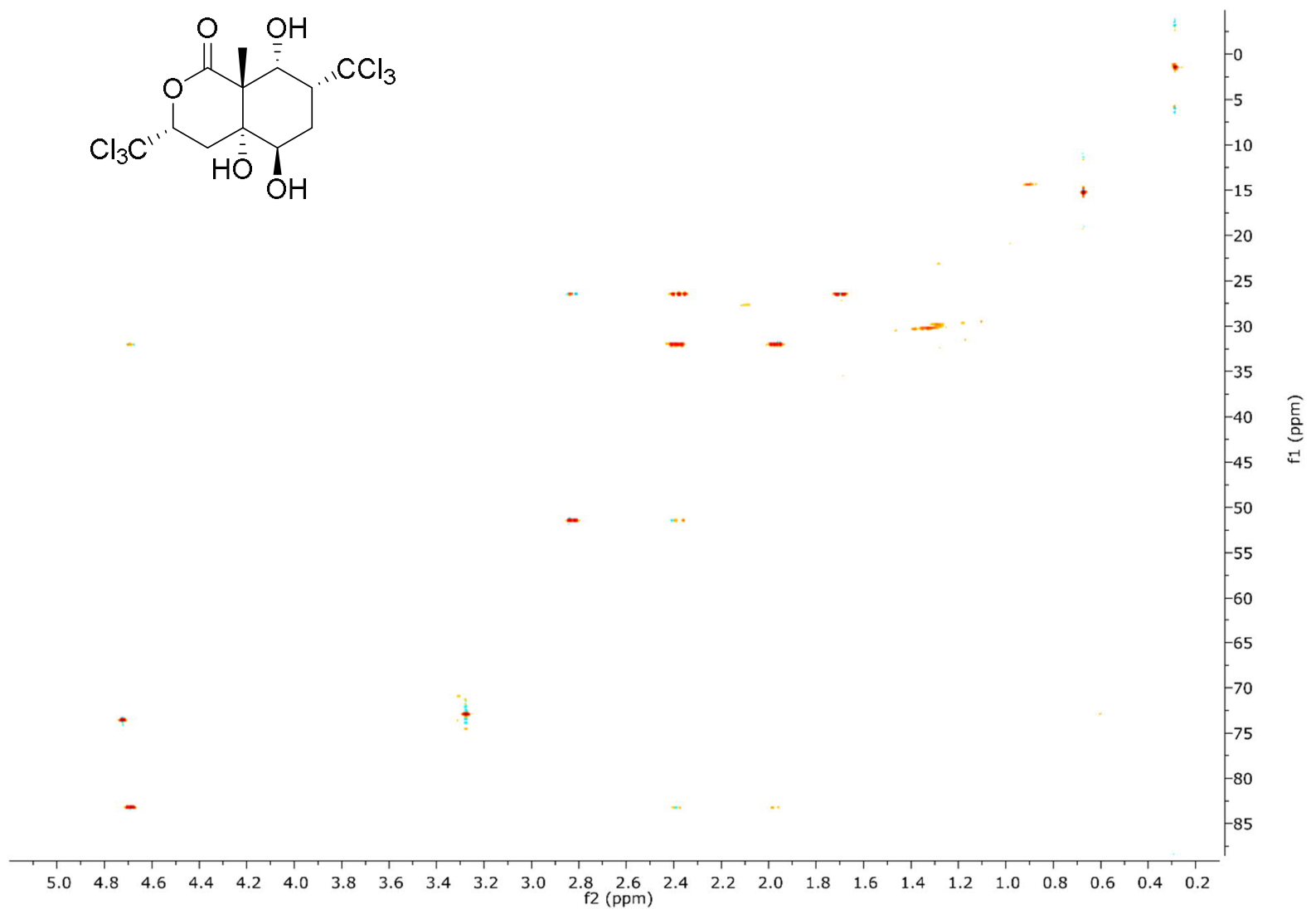

Figure S17. ${ }^{1} \mathrm{H},{ }^{13} \mathrm{C}-\mathrm{HSQC}$-spectrum of sigillin $\mathrm{F}(4)$ in $\mathrm{C}_{6} \mathrm{D}_{6}$. 


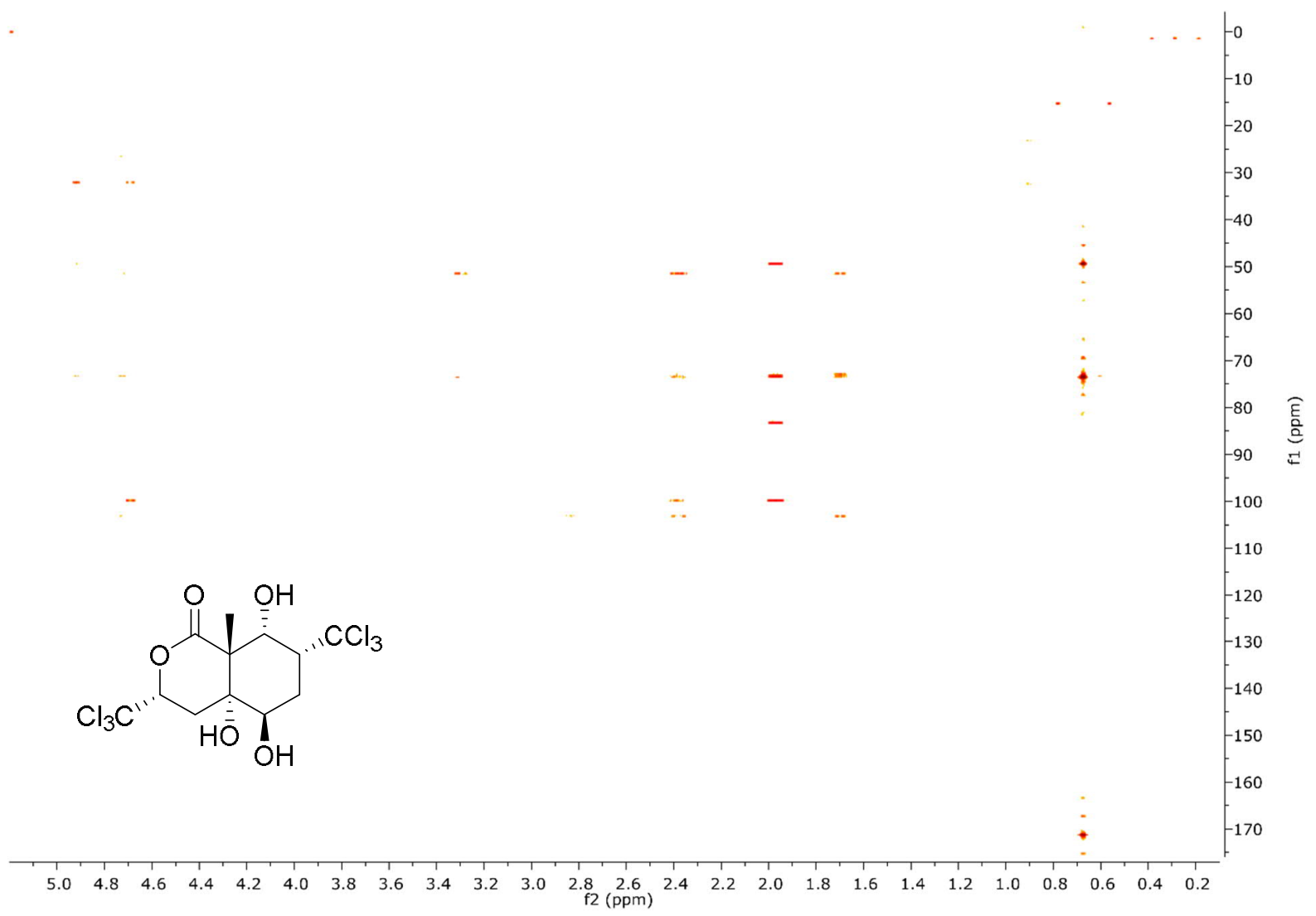

Figure S18. ${ }^{1} \mathrm{H},{ }^{13} \mathrm{C}-\mathrm{HMBC}$-spectrum of sigillin $\mathrm{F}(4)$ in $\mathrm{C}_{6} \mathrm{D}_{6}$. 


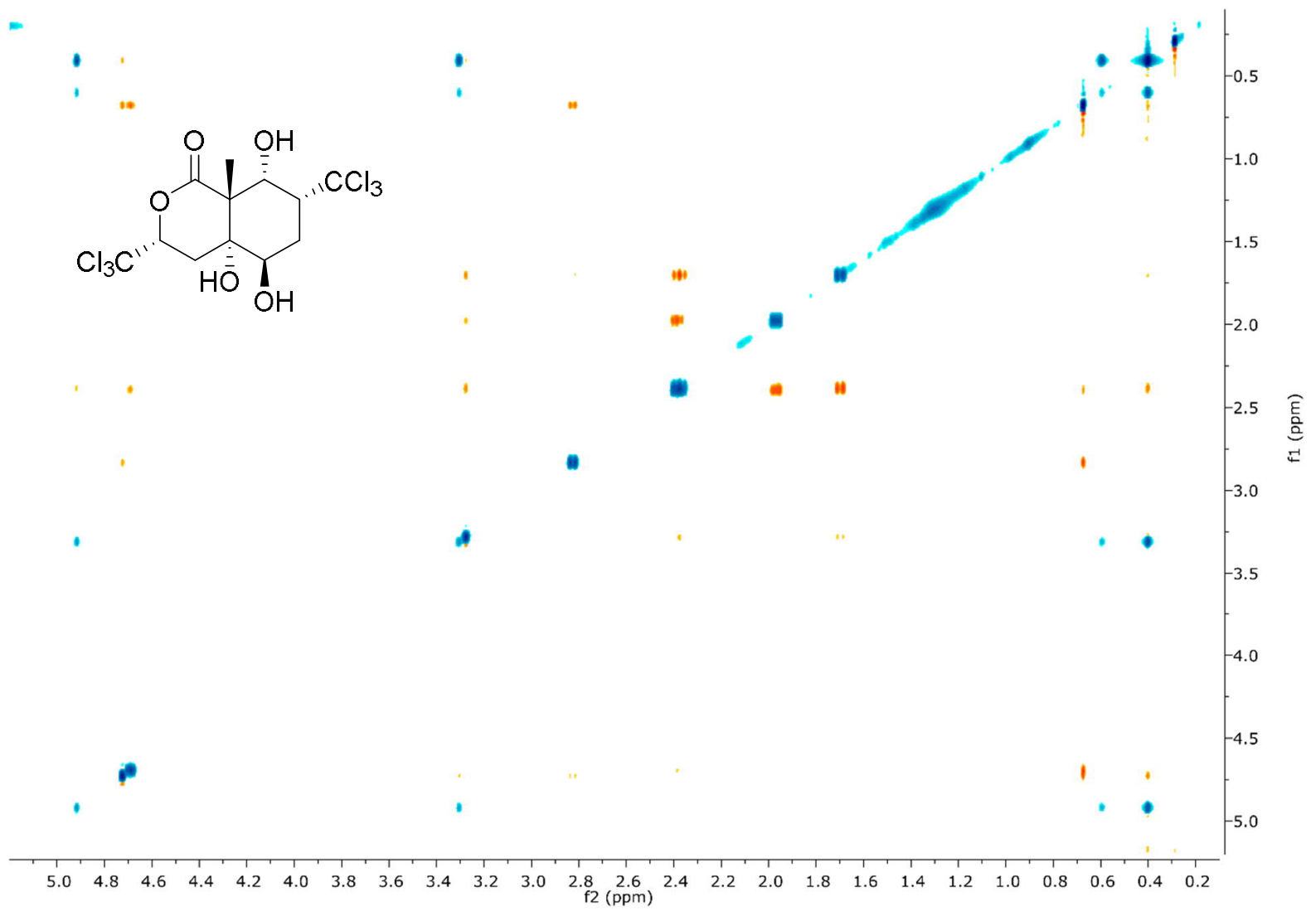

Figure S19. ${ }^{1} \mathrm{H},{ }^{1} \mathrm{H}-\mathrm{NOESY}$-spectrum of sigillin $\mathrm{F}(4)$ in $\mathrm{C}_{6} \mathrm{D}_{6}$. 


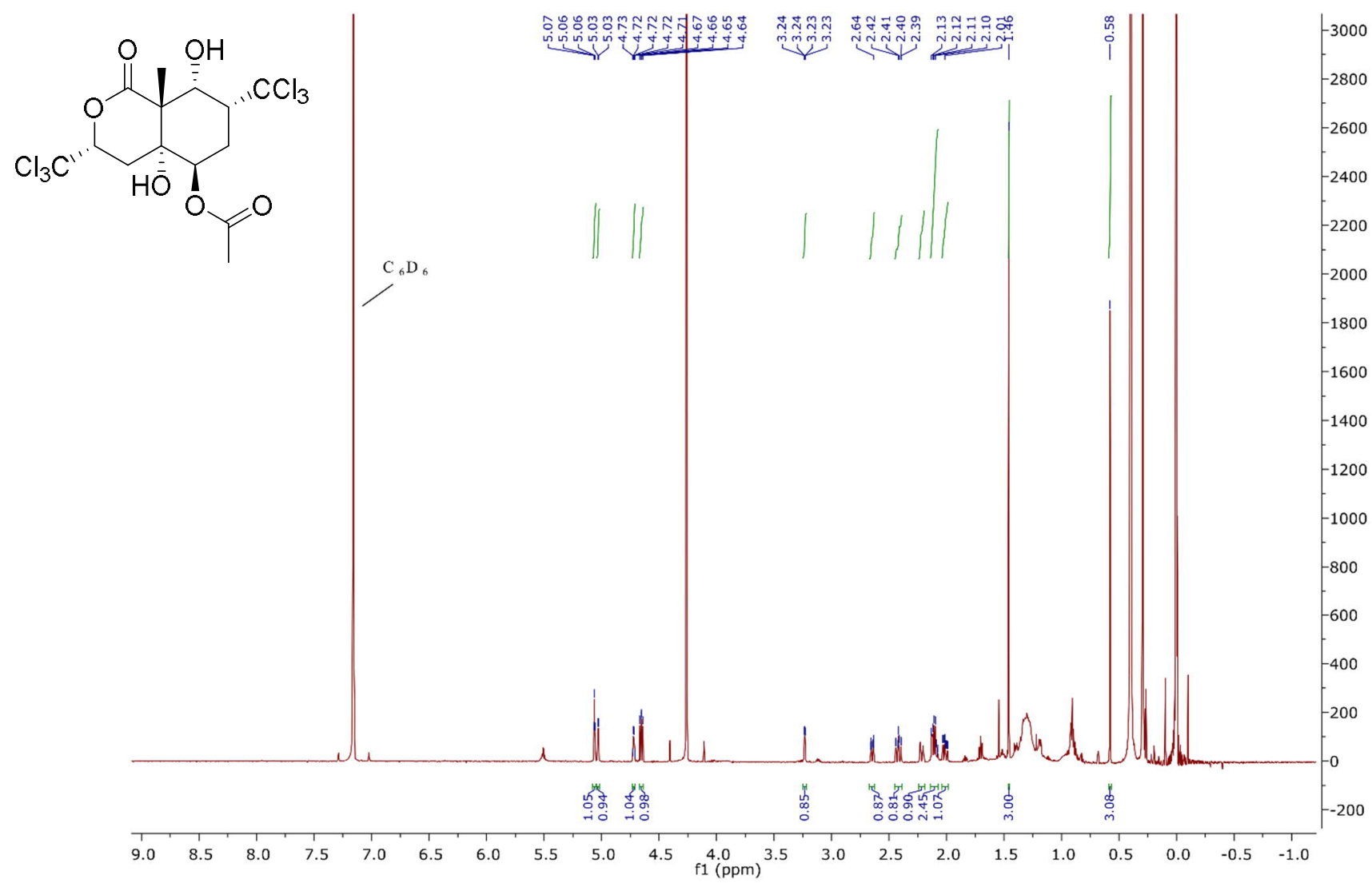

Figure S20. ${ }^{1} \mathrm{H}$ NMR (600 MHz, $\left.\mathrm{C}_{6} \mathrm{D}_{6}\right)$ spectrum of sigillin E (3). 